\title{
Use of Mobile Phones for Project Based Learning by Undergraduate Students of Nigerian Private Universities
}

\author{
Samuel C. Avemaria Utulu \\ RUN Library, Redeemer's \\ University, Redemption City, \\ Ogun State, Nigeria
}

utulus@run.edu.ng

\author{
Ayodele J. Alonge \\ KPMG Professional Services, \\ Lagos, Nigeria
}

ayodele.alonge@ng.kpmg.com

\author{
Oluwafemi S. Emmanuel \\ Dominance Matrix Business Solution, Lagos, Nigeria \\ e olufemi@yahoo.co.uk
}

\begin{abstract}
Material published as part of this publication, either on-line or in print, is copyrighted by the Informing Science Institute. Permission to make digital or paper copy of part or all of these works for personal or classroom use is granted without fee provided that the copies are not made or distributed for profit or commercial advantage AND that copies 1) bear this notice in full and 2) give the full citation on the first page. It is permissible to abstract these works so long as credit is given. To copy in all other cases or to republish or to post on a server or to redistribute to lists requires specific permission and payment of a fee. Contact 0HPublisher@InformingScience.org to request redistribution permission.
\end{abstract}

Contemporary university education is information and communication technology driven because of the information society's influence on the objectives of university education and the way university education is delivered. A university's objective is to educate its students using information and communication technologies (ICTs) and teaching techniques that would enable its graduates become flexible learners that can easily adapt to the changing socio-cultural, technological and economic environment of the information society. Achieving this aim requires among other factors, the adoption of appropriate teaching model such as the project based learning (PBL). PBL has been adjudged as one of the most appropriate teaching models that support the inculcation of collaborative and lifelong learning skills, technology use skills, knowledge sharing skills and social networking skills into students. Consequently, this study was carried out to evaluate the use of mobile phones as knowledge sharing tool by students involved in PBL in three randomly selected private universities in Nigeria. The questionnaire was used as the instrument for data collection from 532 undergraduates students distributed across the three selected private universities. The result showed that as much as $96.6 \%$ of the students evaluated had mobile phones and that they used their mobile phones for communication, interactions, getting information, browsing the Internet, and sharing knowledge anytime they were involved in PBL. It was hoped that the study findings will help in harnessing mobile phones as instructional media and

knowledge sharing technologies in societies that are struggling to rationalize the impact of technology divide on their education.

Keywords: Mobile Phones, Project Base Learning, Nigerian Private Universities, Knowledge Sharing, University Libraries. 


\section{Introduction}

The proliferation of Information and Communication Technologies (ICTs) devices drive and the increase in the quest for their use in educational institutions have not only affected the structure of university education but has also affected the way teaching and learning is done in these institutions. One of the primary factors used to define an information society compliant university is the extent of its infusion of ICTs into its teaching and learning programmes. Hence, teaching and learning techniques in contemporary universities have been continuously redesigned in such a manner that the use of ICTs for their delivery has become sine-qua-non (Al-Khanjari, 2005; Dale \& Povey, 2007; Varis, 2007). The urgent need for the production of information society compliant workforce that are flexible learners and that can easily adapt to the fast changing sociocultural, technological and economic environments has made the provision and adoption of ICTs for teaching and learning in Nigerian universities a primary challenge. In fact, several Nigerian authors have produced scholarly works that assessed the extent to which Nigerian universities have tried to infuse ICT based teaching and learning techniques (Erinosho, 2007; Obanya 2006; Ojokoh \& Asaolu 2005; Olatokun \& Opesade, 2008)

Obanya (2009) also reveals that the models for the delivery of higher education in the information society is distinct and has its own special characteristics. He enumerated six domains of futuristic view of university education in the information society that should define requirements and objectives of university education in Nigeria:

1. assumptions- broad-based and personality development for adaptability

2. student entry- lifelong learning skills with greater emphasis on EQ (Emotional Intelligence Quotient)

3. organization of programs- flexible organization of programs

4. teaching/learning- group and task oriented

5. the teacher- knowledgeable, field-oriented, highly creative, multi disciplinary compliant

6 . the graduate profile- able learner with appropriate intrapersonal and interpersonal capabilities.

He concluded that "higher education [in] today's world has been making a set of futuristic demands [and] a new view of role and mission and functioning..." (p. 227). Adeogun $(2003,2006)$ also outlined that the challenges the information society places before African universities in terms of facility requirements, teaching and learning skills requirements, and the need to frequently update and upgrade teaching models and curriculum is enormous.

Consequently, Project Based Learning (PBL) has been viewed as a very important teaching/learning model that can be used to inculcate e-learning, independent learning and lifelong learning skills required to operate in the information society into university students in the world over. According to Milentijevic et al. (2008) PBL is a:

constructivist pedagogy that intends to bring about deep learning by allowing learners to use an inquiry based approach to engage with issues and questions that are rich, real and relevant to the topic being studied...students are expected to use technology in meaningful ways to help them investigate or present knowledge. (p. 1331)

Newby et al. (2000) opine that "with constructivist strategy, teacher and students share responsibility for directing learning. Students learn by collaborating with one another..." (p. 37). Lee (2009), citing Adderley et al., provides five factors that describe PBL scenarios:

- they involve the solution to a problem often 
- they involve initiative by the student or group of students, and necessitate a variety of educational activities

- they commonly result in an end product

- the work often goes on for a considerable length of time

- teaching staff are involved in an advisory, rather than authoritarian role.

The hallmark of this learning scenario is that it is technology based and also requires students to carryout projects independently; develop strategies among themselves and reach informed conclusions that will help them meet the project objective(s). Within the learning group, technology use for knowledge sharing is paramount. Members are required to work as a team, share knowledge and also reach conclusions that are agreeable to all contributing members of the group. Because of this, PBL has been adjudged to be one of the relevant teaching/learning models that are appropriate for university education in the information society.

However, University education has faired very poorly in Nigeria going by the standards of the information society. Divides such as digital divide, digital knowledge divide and knowledge creation capacity divide have constantly plagued Nigerian universities (Barry et al., 2008; World Bank, 2001). The incessant strike actions embarked upon by the Academic Staff Union of Universities (ASUU) to force Nigerian governments to rationalize these divides have become so frequent that stakeholders are beginning to consider them banes to university education in Nigeria (Okonji, 2007). Irrespective of these obvious factors, Nigerian universities still work towards producing a workforce that can function appropriately in the information society. Hence, tangible and measurable effort like the Nigerian Universities Network (NUNet) which is based on the use of Information Technology (IT) and the Internet to establish academic cooperation, integration and resource sharing among Nigerian universities has been initiated by the National Universities Commission (NUC). Private teaching/learning ICT initiatives in Nigerian private universities have also improved the rate in which ICTs have been made available within the Nigerian university system.

Irrespective of all these efforts, the fact that Nigeria's Internet penetration, student-computer ratio and bandwidth size are still low constitute banes to the appropriate use of ICTs for teaching and learning in Nigerian (http://www.internetworldstats.com). The non-existence of a reliable power sector in Nigeria has also taken its toll on ICT adoption for teaching and learning technique such as the PBL. However, the introduction of Global System for Mobile communications (GSM) and the consequent high use of mobile phones across the country and in university campuses in particular have given rise to reliable alternative for Internet connectivity; online knowledge sharing and technology divide rationalization. The opportunity is capable of serving as a way out for students involved in PBL that are required to use ICTs for their studies and for knowledge sharing. The use of mobile phones for knowledge sharing can be easily attained because most mobile phone sets possess the capacity of an Internet ready mini computer and also have the potential to cover more of the cyberspace using telephony wireless connections. The population of students that own and use mobile phones also justifies this.

However, there are considerable efforts in the literature that cover ICT use for knowledge sharing and for teaching and learning purposes in Nigerian universities, very little effort has been geared toward studying mobile phones as knowledge sharing tools. This is despite the fact that as far back as 2006 Nigeria has large mobile phone subscriber base which was put at about 22.3 out of 100 people (World Bank, 2009). This may have further increased as the sector has expanded in terms of subscribers and GSM service providers.

This study was therefore, carried out to cover the omission of mobile phone studies in the literature. The study was particularly aimed at assessing how mobile technology can be used as reliable 
alternative in a society that digital technology divide has greatly challenged the attainment of its higher education goals. Specifically, the study sets out to:

1. Evaluate the frequency in which Nigerian private university students were involved in PBL

2. Determine the number of students that had and used mobile phones

3. Document mobile phone services available in the mobile phones students enrolled in Nigerian private universities used

4. Examine the frequency of their use of the available services for knowledge sharing when they were involved in PBL

5. Find out the kind of knowledge they used their mobile phones to share when they were involved in PBL

6. Determine the barriers they faced in their quest to use mobile phones as knowledge sharing tools when they were involved in PBL

7. Establish the implication(s) of mobile phone used as knowledge sharing tool on university libraries.

\section{Literature Review}

The information society and its consequent high demand for knowledge production and ICTs use has affected the way education is valued. Most developed societies are adjudged as those with the best philosophy of education that were able to develop sound pedagogy and teaching techniques, and invest in educational research instructional technology and multimedia. It is because of this that research on university education and how to appropriately develop efficient and effective teaching models and techniques have been increasing. These include research areas that deals with how technological innovations of the information society are transforming the ways teachers teach, how learners learn and how societies are adjusting their cultural transmission and socialization processes to the requirements of the information society (Dale \& Povey, 2009; Reis \& Karadag, 2009; Varis, 2007).

In the light of this, Newby et al. (2000) compared three prevalent perspectives of learning: behavioural, information processing and constructivist perspectives. They argued that constructivist perspective (which is the premise upon which PBL is based) requires learners to task their knowledge and environments more than in information processing and behavioural perspectives. Apart from this, they also argued that the level of cognitive processing required to complete tasks in the three perspectives is higher in constructivist perspective. In other words, research on constructivist perspective have been able to establish that PBL tasks learners' knowledge and their cognitive processing more than other learning techniques. Basbay and Ales (2009) studied the effects of PBL on computer student teachers in Ege University and found out among other things that it allowed student to learn from experience, learn to learn and derive social network benefits. Sancho-Thomas et al. (2009) also developed a study to proffer how the social constructivist pedagogical approach can be adopted to teach software development students how to work in teams.

The literature on how technology is being used for knowledge sharing within the ambit of the constructivist perspective like PBL has also been developed. For instance, Al-Khanjari et al. (2005) presented the case of the use of Web-based Instruction through Course Management System (WBI-CMS) in a university in Oman. Their argument was developed from the vital role instructors play in the success of new education initiative and the effects of instructors' awareness of new technologies and their eventual use of new technologies for teaching and knowledge sharing. Enkenberg (2001) looked at collaborative teaching models from the perspective of instructional design with the aim of identifying differences in their effect when applied for individuals or for a group. Woodard (2003) examined the role technology play in creating information rich environment for constructivist based learning and information literacy teaching. 
Recently, studies are beginning to build up on the use of mobile phones for educational purposes. Such studies have relied on the methodologies used in previous studies that dealt with the use of multimedia (Vavoula et al. 2009). Markett et al. (2006) studied the use of short message service (SMS) to encourage interactivity in the classroom between students and teachers. Sharples (2000) also studied how mobile technology is being used to support lifelong learning. Although the literature has covered a lot of issues surrounding PBL as a teaching model, it has also comprehensively dealt with the use of ICTs including mobile phones. One obvious omission in the literature is the non-existence of literature that dealt with the assessment of how mobile phones can be used as knowledge transfer tools in a learning environment and more specifically in a PBL environment. Authors that have assessed PBL looked more at the underlying educational theory behind it. This particular study did not lay emphasis on educational theory underlying PBL, but how students involved in PBL used mobile phones as knowledge sharing tools.

\section{Methodology}

The survey research method was adopted for the study of the use of mobile phones for PBL by undergraduate students of three private universities in Southwestern Nigeria. The questionnaire was adopted as the primary data collection instrument, while simple random technique was used to select three- (Lagos, Ogun, \& Osun) States- of the six Southwestern Nigerian states where the universities that participated in the study are located. There were 18 private universities in Southwestern Nigeria, which were estimated to be $43.9 \%$ of the total number of private universities in Nigeria. Three private universities situated in the three randomly selected states were also randomly selected to participate in the study. The student population of three universities was estimated to be about 6000 students, that is, about 2000 students each. The stratified sampling technique was used to select 750 students, that is, 250 students from each of the participating private universities as the sample population. The sample population represented $12.5 \%$ of the study population. The stratified sample technique allowed only students in their second, third and fourth years in the university with appropriate university education experience to participate in the study. However, the response rate recorded was as follows: Redeemer's University (RUN): 203, Joseph Ayoola Babalola University (JABU): 198 and Caleb University (CALEB): 131, which amounted to $532(71.0 \%)$ response rate.

\section{Findings}

\section{Demography and Mobile Phone Ownership}

All the respondents were undergraduates distributed across three academic years as follows: second year: $245(46.3 \%)$, third year: $125(23.5 \%)$ and fourth year: $162(30.5 \%)$. It was revealed that over half of the respondents, that is, $315(59.2 \%)$ were between the age range of 16 and 20 years. $181(34.0 \%)$ of the respondents also claimed that they were between the age range of 21 and 25 , while $22(4.1 \%)$ were between the age range of 26 and 30 years. However, $14(2.6 \%)$ did not indicate their age ranges. The age range disparity which skewed towards respondents within the age range of 16-20 years may have resulted from the high percentage of respondents in their second year in the university and the new trends in age distribution of university students and candidates seeking admissions into universities globally. Obanya (2006) commented on this thus: “...yesterday's [pre-information society] university student was an adult, while tomorrow's [information society] student will be an adolescent."

$303(57.0 \%)$ of the respondents reported that they were female, while $205(38.5 \%)$ reported that they were male. $24(4.5 \%)$ did not report their gender type. 
The distribution of respondents academic disciplines showed that they were distributed into three faculties/colleges: Natural and Applied Sciences, Management/Social Sciences and Humanities. Specifically, 319 (60.0\%) of the respondents claimed that their academic discipline was Management/Social Science based. 108 (20.2\%) claimed that their academic disciplines were Natural and Applied Science based, while 109 (20.7 \%) claimed that their academic discipline was in the humanities. It was revealed that as much as $512(96.6 \%)$ of the respondents had mobile phones, while $12(2.3 \%)$ did not have mobile phones. However, $4(0.8 \%)$ have lost their mobile phones, another $4(0.8 \%)$ claimed that their mobile phones got spoilt.

However, $287(56.1 \%)$ of the respondents claimed that they had mobile phones had one mobile phone set each, $206(40.2 \%)$ had two mobile phone sets, while $19(3.7 \%)$ had three mobile phone sets. It was also revealed that 403 were Nokia, 87 were Samsung, 23 were LG, 36 were Motorola, while 90 were other kinds mobile phone sets (Sony-Eriksson, Dorado, Sagem, etc.).

\section{Mobile Phone Services and Use of Mobile Phones for PBL}

Analysis of the frequency of respondents involvement in PBL showed that only $81(15.2 \%)$ claimed that the frequency of their involvement in PBL was very often. 151 (28.4\%) claimed their involvement in PBL is often. $63(11.8 \%)$ were not sure of the frequency of their involvement in PBL. However, 138 (25.9\%) claimed that they were not often involved in PBL. 92 (17.3 $\%$ ) of the respondents claimed also that they did not very often involve in PBL. 7 (1.4\%) of the respondents did not respond to the frequency of their involvement in PBL.

Table 1: Distribution of Mobile Phone Services Available in Respondents Mobile Phone Sets

\begin{tabular}{|l|l|l|l|}
\hline S/N & Mobile Phone Services & Number & Percentage \\
\hline $\mathbf{1}$ & Voice Calls & $\mathbf{5 3 2}$ & $\mathbf{1 0 0}$ \\
\hline $\mathbf{2}$ & Short Message Service (SMS) & $\mathbf{5 3 2}$ & $\mathbf{1 0 0}$ \\
\hline 3 & Internet Services & 412 & 77.4 \\
\hline 4. & Multimedia Message Service (MMS) & 411 & 77.3 \\
\hline 5. & Camera & 401 & 75.4 \\
\hline 6. & Radio & 386 & 72.6 \\
\hline 7. & Voice Mail & 385 & 72.4 \\
\hline 8 & Audio Recording & 371 & 69.7 \\
\hline 9. & Television (TV) & 80 & 15.0 \\
\hline
\end{tabular}

Voice calls and SMS facilities were available in all the mobile phone sets owned by the respondents. Only television facilities were not widely available among the facilities listed in Table 1. 
Table 2: Distribution of Respondents Self Assessment of the Frequency of their Use of Available Mobile Phone Services when they were Involved in PBL

\begin{tabular}{|l|l|l|l|l|l|l|l|l|l|l|l|l|l|l|l|}
\hline $\begin{array}{c}\text { Mobile } \\
\text { Phone Ser- } \\
\text { vices }\end{array}$ & \multicolumn{2}{|c|}{$\begin{array}{c}\text { Very Of- } \\
\text { ten }\end{array}$} & \multicolumn{2}{|c|}{ Often } & \multicolumn{2}{|c|}{ Not Sure } & \multicolumn{2}{|c|}{ Not Often } & \multicolumn{2}{|c|}{$\begin{array}{c}\text { Not Very } \\
\text { Often }\end{array}$} & \multicolumn{2}{|l|}{ Not At All } & \multicolumn{2}{|c|}{$\begin{array}{c}\text { No Re- } \\
\text { sponse }\end{array}$} \\
\hline & No. & $\%$ & No. & $\%$ & No. & $\%$ & No. & $\%$ & No. & $\%$ & No. & $\%$ & No. & $\%$ \\
\hline Voice Calls & $\mathbf{2 4 0}$ & $\mathbf{4 5 . 1}$ & $\mathbf{9 0}$ & $\mathbf{1 6 . 9}$ & $\mathbf{2 4}$ & $\mathbf{4 . 5}$ & $\mathbf{6 6}$ & $\mathbf{1 2 . 4}$ & $\mathbf{2 2}$ & $\mathbf{4 . 1}$ & $\mathbf{8 7}$ & $\mathbf{1 6 . 4}$ & $\mathbf{3}$ & $\mathbf{0 . 6}$ \\
\hline SMS & $\mathbf{2 7 4}$ & $\mathbf{5 1 . 5}$ & $\mathbf{1 3 9}$ & $\mathbf{2 6 . 1}$ & $\mathbf{1 5}$ & $\mathbf{2 . 8}$ & $\mathbf{3 1}$ & $\mathbf{5 . 8}$ & $\mathbf{2 5}$ & $\mathbf{4 . 7}$ & $\mathbf{4 5}$ & $\mathbf{8 . 5}$ & $\mathbf{3}$ & $\mathbf{0 . 6}$ \\
\hline MMS & 58 & 10.9 & 75 & 14.1 & 41 & 7.7 & 98 & 18.4 & 55 & 10.3 & 198 & 37.2 & 7 & 1.4 \\
\hline Voice Mail & 58 & 10.9 & 40 & 7.5 & 32 & 6.0 & 81 & 15.2 & 50 & 9.4 & 266 & 50.0 & 5 & 1.0 \\
\hline $\begin{array}{l}\text { Internet } \\
\text { Services }\end{array}$ & $\mathbf{2 0 2}$ & $\mathbf{3 8 . 0}$ & $\mathbf{9 4}$ & $\mathbf{1 7 . 7}$ & $\mathbf{2 5}$ & $\mathbf{4 . 7}$ & $\mathbf{3 9}$ & $\mathbf{7 . 3}$ & $\mathbf{2 6}$ & $\mathbf{4 . 9}$ & $\mathbf{1 4 1}$ & $\mathbf{2 6 . 5}$ & $\mathbf{5}$ & $\mathbf{1 . 0}$ \\
\hline Radio & 115 & 21.6 & 98 & 18.4 & 23 & 4.3 & 42 & 7.9 & 32 & 6.0 & 214 & 40.2 & 6 & 1.2 \\
\hline TV & 39 & 7.3 & 61 & 11.5 & 9 & 1.7 & 41 & 7.7 & 20 & 3.8 & 356 & 66.9 & 6 & 1.2 \\
\hline $\begin{array}{l}\text { Audio Re- } \\
\text { cording }\end{array}$ & 101 & 19.0 & 80 & 15.0 & 34 & 6.4 & 71 & 13.3 & 35 & 6.6 & 205 & 38.5 & 5 & 1.0 \\
\hline $\begin{array}{l}\text { Video Re- } \\
\text { cording }\end{array}$ & 119 & 22.4 & 82 & 15.4 & 44 & 8.3 & 55 & 10.3 & 34 & 6.4 & 193 & 36.3 & 5 & 1.0 \\
\hline Camera & 153 & 28.8 & 76 & 14.3 & 21 & 3.9 & 30 & 5.6 & 31 & 5.8 & 216 & 40.6 & 5 & 1.0 \\
\hline
\end{tabular}

As shown in Table 2, three mobile phone services were significantly used by respondents anytime they were involved in PBL. The three services (Voice Calls, SMS and Internet Services) are actually related to services used for communicating, sharing information and knowledge and getting information and knowledge.

Table 3: Distribution of Respondents Self-Assessment of what they Use Mobile Phone for when they were Involved in PBL

\begin{tabular}{|l|l|l|l|}
\hline S/N & Mobile Services & Number & Percentage \\
\hline $\mathbf{1 .}$ & To Get Information from members of PBL Group & $\mathbf{4 1 3}$ & $\mathbf{7 7 . 6}$ \\
\hline $\mathbf{2 .}$ & Communication Directives & $\mathbf{3 9 7}$ & $\mathbf{7 4 . 6}$ \\
\hline $\mathbf{3 .}$ & Communicate new findings & $\mathbf{3 9 5}$ & $\mathbf{7 4 . 2}$ \\
\hline $\mathbf{4 .}$ & Browse the Internet & $\mathbf{3 5 0}$ & $\mathbf{6 5 . 8}$ \\
\hline 5. & Communicate with lecturer in charge of course & 306 & 57.5 \\
\hline 6. & Collect Data, e.g. recordings & 262 & 49.2 \\
\hline 7. & Send Email to members of the PBL Group & 176 & 33.1 \\
\hline 8. & Access OPAC & 155 & 29.1 \\
\hline 9. & Send Email to lecturer & 143 & 26.9 \\
\hline
\end{tabular}

Table 3 revealed that mobile phones were used by respondents to interact, get information and share knowledge. The interaction may have been in the form of communicating (directive and new findings) between respondents involved in PBL. Also, respondents claimed that they get 
information from the Internet using their mobile phones when they were involved in PBL. They also shared knowledge in the form of new findings from their PBL experience. The use of mobile phones to access Online Public Access Catalogue and to send emails was not popular among respondents.

Table 4: Distribution of Barriers Impeding Respondents' Use of Mobile Phones for PBL

\begin{tabular}{|c|c|c|c|c|c|c|c|c|c|c|c|c|c|c|}
\hline \multirow[t]{2}{*}{ Barriers } & \multicolumn{2}{|c|}{ No Effect } & \multicolumn{2}{|c|}{$\begin{array}{l}\text { Lowest } \\
\text { Value }\end{array}$} & \multicolumn{2}{|c|}{$\begin{array}{l}\text { Low } \\
\text { Value }\end{array}$} & \multicolumn{2}{|c|}{ Mid Point } & \multicolumn{2}{|c|}{$\begin{array}{l}\text { High } \\
\text { Value }\end{array}$} & \multicolumn{2}{|c|}{$\begin{array}{l}\text { Highest } \\
\text { Value }\end{array}$} & \multicolumn{2}{|c|}{$\begin{array}{l}\text { No Re- } \\
\text { sponse }\end{array}$} \\
\hline & No & $\%$ & No & $\%$ & No & $\%$ & No & $\%$ & No & $\%$ & No & $\%$ & No & $\%$ \\
\hline Cost & 58 & 10.9 & 15 & 2.8 & 41 & 7.7 & 121 & 22.7 & 84 & 15.8 & 210 & 39.5 & 3 & 0.6 \\
\hline $\begin{array}{l}\text { Access to Alter- } \\
\text { natives }\end{array}$ & 92 & 17.3 & 26 & 4.9 & 29 & 5.5 & 130 & 24.4 & 90 & 16.9 & 165 & 31.2 & 3 & 0.6 \\
\hline $\begin{array}{l}\text { Reliability of } \\
\text { Mobile Lines }\end{array}$ & 201 & 37.8 & 59 & 11.1 & 34 & 6.4 & 104 & 19.5 & 49 & 9.2 & 80 & 15.9 & 3 & 0.6 \\
\hline $\begin{array}{lr}\text { Mobile } & \text { Phone } \\
\text { Capacity } & \end{array}$ & 206 & 38.7 & 45 & 8.5 & 30 & 5.6 & 82 & 15.4 & 60 & 11.3 & 104 & 19.5 & 5 & 1.0 \\
\hline $\begin{array}{l}\text { Affordability of } \\
\text { Mobile Phone } \\
\text { with Required } \\
\text { Capacity }\end{array}$ & 265 & 49.8 & 59 & 11.1 & 31 & 5.8 & 63 & 11.1 & 45 & 8.5 & 64 & 12.0 & 5 & 1.0 \\
\hline $\begin{array}{l}\text { Usability } r \\
\text { Mobile Phone } \\
\text { Keyboards }\end{array}$ & 228 & 42.9 & 43 & 8.1 & 34 & 6.4 & 117 & 22.0 & 50 & 9.4 & 57 & 6.7 & 3 & 0.6 \\
\hline $\begin{array}{l}\text { Size of Mobile } \\
\text { Phone Screen }\end{array}$ & 195 & 36.7 & 66 & 12.4 & 35 & 6.6 & 91 & 17.1 & 54 & 10.2 & 86 & 16.2 & 5 & 1.0 \\
\hline $\begin{array}{l}\text { No Electricity to } \\
\text { Charge Mobile } \\
\text { Phone Regularly }\end{array}$ & 267 & 50.2 & 42 & 7.9 & 38 & 7.1 & 75 & 14.1 & 32 & 6.0 & 73 & 13.7 & 5 & 1.0 \\
\hline
\end{tabular}

Two barriers prevalent among the factors that impeded the use of mobile phones for PBL were cost of using mobile phones as knowledge sharing tool and availability of, and access to alternative knowledge sharing tools. In other word, respondents claimed that their use of mobile phones for factors measured in the study was limited by their access to alternative technologies. Surprisingly, issues like availability of power to recharge mobile phone sets, usability of mobile phone set due to keyboard and screen sizes did not constitute barriers to the extent respondents used mobile phones when they were involved in PBL.

\section{Discussions}

One of the primary observations in this study was the low frequency of respondents' involvement in PBL. Despite the importance of PBL to contemporary university education, the universities studied seems not to be keen on using PBL as a primary teaching and learning technique. Considering the fact that the constructivist theory upon which PBL is based helps learners to imbibe flexible learning, collaborative learning and social networking skills that are important skills in the information society, the respondents may have been robbed of these skills due to the limited number of times they have been involved in PBL and may question their ability to operate under conditions prevalent in the information society. Another primary observation is the age range distribution where over half of the respondents were between the age range of 16 and 20 years. Surprising as this may be, it is in line with Obanya (2006) position that the university student 
body of the information society would undergo a significant age distribution change. Also, the gender distribution may have resulted from the dividend of the growing enlightenment on gender issues in Nigeria especially in the Southwestern states where the study was conducted. Apart from this, majority of the students in Nigerian private universities belong to high income homes that can afford the cost of private university education and were access is easier than publicly owned universities.

Mobile phones were popular among the respondents as revealed by the percentage of respondents that had mobile phones. This revealed the non-existence of mobile phone divide among the respondents. Also, the study revealed that the mobile phone sets respondents claimed that they had had mobile phone services that can support knowledge creation and sharing. This was exemplified by available services listed in Table 1 that can support verbal communication, text communication, multimedia data creation and communication, audio recording and communication, and creation of photographs using mobile phone camera. Available services in respondents' mobile phones pointed to the fact that respondents who may want to use mobile phones to share knowledge when involved in PBL can easily do so.

However, of the ten mobile phone services evaluated in the study only three (Voice Calls, SMS and Internet Services) were very often and often used by respondents when involved in PBL. This may lead to an assumption that respondents communicated tacit knowledge more with mobile phones when involved in PBL than recorded knowledge. Oppenheim et al. (2003, p. 161) have put forward that tacit knowledge is "personal knowledge and intuition, embedded in individual experience, and is usually shared and exchanged through direct face-to-face contact...it can be communicated quite quickly..." Table 4 may be used to support this assumption. The Table revealed that a significant percentage $(77.6 \%)$ of the respondents used their mobile phones to get information from other students in their PBL group. Other significant uses of mobile phone services recorded in the study were for communication of directives and new findings to members of the PBL group. The numbers of respondents that used their mobile phones to browse the Internet for resources they needed to complete their tasks were not as much as those that used their mobile phones for communication. However, the fact that more than half of the respondents used their mobile phones to access the Internet when involved in PBL revealed a new sources of Internet access among university students. It showed that students did not have to be in cyber cafés, in the library or own an expensive laptop to access the Internet.

Of significant interest about the outcome of this study were the barriers respondents claimed they faced in their bid to use mobile phones when involved in PBL. Cost of using mobile phones for PBL and access to alternative knowledge sharing technologies, constituted significant barriers to the respondents out of the eight barriers listed in the study. Cost in this context may have been expressed in terms cost of buying airtime and the cost of using each of the available mobile phone services. For instance, the average cost for sending an SMS is 15:00, about ten cents, while voice calls per minute costs between $\$ 45: 00$ and $\$$ 50:00 (about 30 to 35 cents). Sharing tacit knowledge and recorded information or communicating directives could take minutes, and therefore can constitute high cost.

Availability of alternatives, which may include free access to computers and the Internet in the library, cybercafés and personally owned laptops and PCs, were recorded as significant barriers. The effect of alternative technologies on the use of mobile phones as knowledge sharing tools may have emanated from cost and/or ergonomic factors. Respondents may have found PCs and Laptops more convenient to use than mobile phones, especially for sending mails, downloading and uploading resources and as storage devices. Again, access to alternative free information sources within university library is a likely factor. This is because Internet access in university libraries are most likely to be free and may be a better choice than mobile phones. This may justify why most of the respondents did not use their mobile phones to access OPAC. Interestingly, 
all the barriers evaluated in the study had effects at varying levels, which points to the fact that mobile phone use for knowledge sharing by respondents was not devoid of barriers

\section{Implication for University Libraries}

University libraries all over the world have been faced with challenges of meeting the growing information needs of their users, more so when they are involved in PBL which is knowledge and technology-use tasking. The result of this study may provide university libraries with basic knowledge of how students' mobile phones can serve as alternatives for rationalizing the technology divide which has rocked Nigerian universities. Since mobile phone have the capacities of mini computers and can be used to access the Internet, they therefore become very important technology for students use. University libraries can begin to work out ways in which management, administrators, lecturers, librarians and students can better harness mobile phones as instructional technology that can be used to generate information and share knowledge. Obviously, mobile phones can be used as a reference tool by librarians; their cameras can be used as tools for creating digital resources from non-digitally born resources and for sharing recorded knowledge available only in the library. Although this new practice may raise copyright question; there is every need for librarians to educate students on how to use mobile phones within the confines of existing copyright law. The ability of librarians to innovate ways they could use mobile phones in library context of information management, for teaching and for learning will definitely improve mobile phone use beyond the ways that have been revealed in this study.

\section{Conclusion}

Mobile phones represent new and fast growing development in ICTs innovation. Their adoption for teaching and learning models that have been adjudged information society compliant has also been growing. It has been reported so far that mobile phones are reliably used by students involved in PBL for knowledge sharing, although at a rate which can be described as basic and uncoordinated. The prospect revealed in the study is that mobile phones posses the potential to become very reliable instructional technology that can be used by lecturers and librarians to achieve feats that have been hampered by technology divide. The fact that mobile phones can be used at any location where teaching and learning are taking place and still receive Internet signals made them unique. However, much is still left to be done in terms of harnessing them for educational purposes and this may need the collaboration of various stakeholders. If proper assessment is done universities in a country like Nigeria with long history of digital divide would make out good alternative to instructional technologies from mobile phones.

\section{References}

Adeogun M. (2003). The digital divide and university education system in sub-Saharan Africa. African Journal of Library, Archives and Information Science, 13(1), 11-20.

Adeogun, M. (2006). The challenges of a modern tertiary education system: Paradigm shifts for educators and information professionals in sub-Saharan Africa. African Journal of Library, Archival and Information Science, 16 (1), 45-52.

Al-Khanjari, Z., Kutti, N., \& Dorvlo, A. (2005). Preparedness for the introduction of e-learning in higher education-The case of Oman. Journal of Social Science, 1(2), 92-98.

Barry, B., Chukwuma, V., Petitdidier, N. Cottrell, L., \& Barton, C. (2008). Digital divide in sub-Saharan African universities: Recommendations and monitoring. Paper Presented at the IST-Africa Conference Proceedings, P. Cunningham and M. Cunningham (Eds.). Available at: www.ISTAfrica.org/conference2008 Accessed on 23/4/2009. 
Basbay, M., \& Ales, A. (2009). The reflections of student teachers on project based learning and investigating self evaluation versus teacher evaluation. Procedia social and Behavioural Sciences, 1, 242-247.

Dale, C., \& Povey, G. (2009). An evaluation of learner-generated content and podcasting. Journal of Hospitality, Leisure, Sport and Tourism, 8(1), 117-123.

Enkenburg, J. (2001). Instructional design and emerging teaching modes in higher education. Computers in Human Behavior, 17, 495-506.

Erinosho, O. (2007). The quality of Nigeria's private universities. Ibadan Journal of Social Sciences, 5(1), $1-15$.

Internet Stats. (2010). Accessed on January 152010 from http://www.internetworldstats.com/africa.htm

Lee, N. (2009). Project methods as the vehicle for learning in undergraduate design education: A typology. Design Studies, 30, 541-560.

Markett, C., Sanchez, A., Weber, S., \& Tangney, B. (2006). Using short message service to encourage interactivity in the classroom. Computers \& Education, 46, 280-293.

Milenjevic, I., Ciric, V., \& Vojinovic, O. (2008). Version control in project-based learning. Computers \& Education, 50, 1331-1338.

Newby, T. Stepich, D. Lehman, J., \& Russell, J. (2000). Instructional technology for teaching and learning: Designing instruction, integrating computers, and using media. New Jersey: Prentice Hall.

Obanya, P. (2006). Tomorrow's university. A paper delivered at Babcock University Symposium, Babcock University, Ogun State, Nigeria, August 15.

Obanya, P. (2009). Dreaming, living and doing education. Ibadan: Educational Research and Study Group.

Ojokoh, B., \& Asaolu, M. (2005). Studies on internet access and usage by students of the Federal University of Technology, Akure, Nigeria. African Journal of Library, Archives and Information Science, 15 (2), 149-153.

Okonji, A. (2007). ASUU strike as tool for educational reforms and management of universities in Nigeria. In J. Babalola \& B. Emunemu (Eds.), Issues in Higher Education: Research Evidence from SubSaharan Africa (pp. 193-199). Ikeja: Bolabay Publications.

Olatokun, W., \& Opesade, O. (2007). An e-readiness assessment of Nigeria's premier university (Part 1). International Journal of Education and Development Using ICT, 4(2), 1-32.

Oppenheim, C., Stenson, J., \& Wilson, R. (2003). Studies on information as an asset I: Definitions. Journal of Information Science, 29(3): 159-166.

Reis, Z., \& Karadag, Z. (2009). A new model for collaborative learning in computer based mathematics instruction: 4s. Procedia social and Behavioural Sciences, 1, 1949-1956.

Sancho-Thomas, P., Fuentes-Fernandez, R., \& Fernandez-Manjon, B. (2009) Learning teamwork skills in university programme courses. Computers \& Education, 53, 517-531.

Sharples, M. (2000). The design of personal mobile technologies for lifelong learning. Computers \& Education, 34, 177-193.

Varis, T. (2007). New technologies and innovation in higher education and regional development. Revista de Universidad y Sociedad del Conocimiento, 4(11), 16-24.

Vavoula, G., Sharples, M., Rudman, P., Meek, J., \& Lonsdale, P. (2009). Myartspace: Design and evaluation of support for learning with multimedia phones between classrooms and museums." Computers \& Education, 53, 286-299.

Woodard, B. (2003). Technology and the constructivist learning environment: Implications for teaching information literacy skills. Research Strategies, 19, 181-192.

World Bank. (2001). Building capacity to deliver distance education in Nigeria's Federal University System. Vancouver: COL International. 
World Bank. (2009). African development indicators 2008/09: Youth and employment in Africa: The potential, the problem, the promise. Washington: The World Bank.

\section{Biographies}

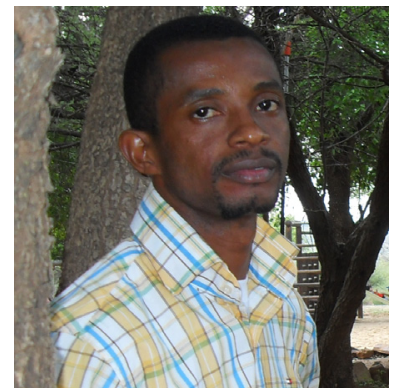

Samuel C. Avemaria Utulu is currently the Acquisitions Librarian in the RUN Library, Redeemer's University (RUN), Redemption City, Nigerian. He has served in the capacity of a Systems Librarian in the same university and also in Bells University of Technology, Ota, Nigeria. He attained his bachelor degree in Library and Information Studies and Masters of Information Science from the Department of Library, Archival and Information Studies and the Africa Regional Centre for Information Science at the University of Ibadan, Nigeria respectively. His research interest is in electronic publishing-open access publishing, webology, adoption of the Internet for library management and electronic information management.

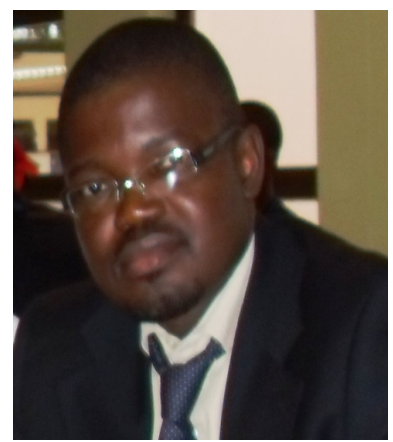

Ayodele John Alonge holds a Bachelors Degree in Library and Information Studies (BLIS) and Masters of Publishing and Copyright Studies (MPCS) from the University of Ibadan, Nigeria. He is a member of the Nigerian Library Association (NLA) and an Associate of Chartered Institute of Library and Information Professionals (CILIP), United Kingdom. His research interests are: Information and Media Literacy (IML), Electronic Publishing and Social Networking and Librarianship. He won the Dr. James of Daniel Award for the most innovative Library-based ICT project of the NLA in 2009 for his explorations on application of social networking in librarianship. He works as a Librarian at the KPMG Professional Services, Lagos, Nigeria.

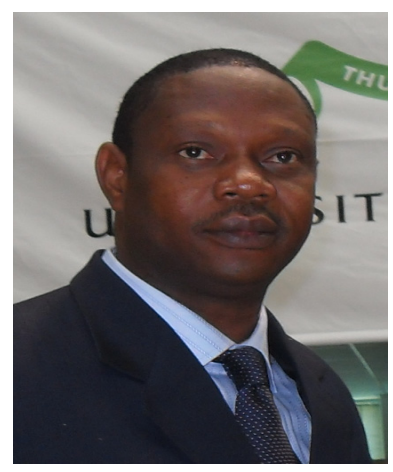

Emmanuel, Oluwafemi Samuel holds a Master Degree in Information Science from the University of Ibadan, Nigeria. He is a member of Associate Accounting Technicians (AAT) of the Institute of Chartered Accountant of Nigerian and an accredited management trainer by the Nigerian Council for Management Development and by extension Training Manager with Dyson School of Management, Lagos, Nigeria. $\mathrm{He}$ is currently undergoing a graduate study in Business Administration from the Obafemi Awolowo University (OAU), Nigeria. Mr. Emmanuel is the MD/CEO of Dominance Matrix Business Solutions, and also a Pastor and Regional Overseer with the Mountain of Fire and Miracles Ministries Worldwide with headquarters in Lagos, Nigeria. 